\title{
Farmers' soil knowledge, fertility management logic and its linkage with scientifically analyzed soil properties in southern Ethiopia
}

\author{
Fanuel Laekemariam ${ }^{1 *}$, Kibebew Kibret $^{2}$ and Tekalign Mamo ${ }^{3}$
}

\begin{abstract}
Background: Farmers' locally have acquired knowledge from generations of experience and experimentation that fit local conditions. Yet, the scientific approach less used farmers' soil knowledge (FSK) and site-specific soil information. The objectives of this study were to investigate FSK and rationality; to demonstrate how FSK relates to scientifically analyzed soil properties; and to explore the implemented soil management practices and crop performances in selected districts of Wolaita zone, southern Ethiopia. A total of 789 farmers were included, and their fields were evaluated. Data on farmer's soil nomenclature, soil physicochemical property, soil fertility management practices and crop yield performance were recorded and analyzed.
\end{abstract}

Results: Farmers describe and classify their soils using holistic approach. Soil nomenclature and classification indicators are relatively homogeneous over large area. Accordingly, seven soil types common over large area were identified. Mostly, soil types perceived fertile by farmers (e.g., Arrada bita) were found better in measured physicochemical properties than infertile soil types (e.g., Lada bita, Zo'o bita). Simple regression analysis revealed a declining trends of soil properties with a decrease in fertility of farmers soil types such as soil bulk density $\left(r^{2}=0.78\right), \mathrm{pH}\left(r^{2}=0.53\right)$, available phosphorous $\left(r^{2}=0.83\right)$, total exchangeable bases $\left(r^{2}=0.71\right)$, copper $\left(r^{2}=0.64\right)$ and zinc $\left(r^{2}=0.69\right)$. Farmers are rational to allocate the scarce fertilizers. They apply more chemical fertilizer when soil type was getting poor in soil fertility $\left(r^{2}=0.61\right)$, whereas it was opposite for manure $\left(r^{2}=0.85\right)$. Furthermore, crop response and farmers' soil type also demonstrated an observable relationship where yield was declining with a decrease in fertility level of farmers' soil types.

Conclusions: Farmers understand within farm soil variability and exploit soil fertility differences of their field. This is supported with noticeable relationship with scientifically analyzed soil properties, fertility management strategy and crop responses. It suggests that FSK is relevant for site-specific soil management. Yet, FSK is deficient to identify yieldlimiting nutrients, implying it has to be complemented with scientific soil knowledge. Additionally, further investigation to systematically link both approaches is also suggested.

Keywords: Farmer'soil nomenclature, Physicochemical property, Soil variability, Yield

\section{Background}

Soil fertility management is an agenda of farmers and scientists as soil properties are characterized by spatial and

\footnotetext{
*Correspondence: laeke2005@yahoo.com

1 Department of Plant Science, College of Agriculture, Wolaita Sodo University, Wolaita Sodo, Ethiopia

Full list of author information is available at the end of the article
}

temporal variability to the extent of short distances [1-3]. This heterogeneity can be caused by inherent properties and external factors such as farmers' differences in soil management [4-6] and land use [1]. Without systematic consideration of different soil types, soil nutrient management interventions have proved to be risky interventions and have failed to constitute economically 
valid options [7]. Soil interventions in most African countries, in general, have been dominated by the scientific thinking; soil management aspects are dominated by discussions of inorganic fertilizers [8] and blanket recommendations [3]. Yet, the scientific approach less used farmers' soil knowledge (FSK) and site-specific soil information $[9,10]$; subsequently, this leads to the poor adoption of recommendations such as fertilizer use. On contrary, farmers have been accused of ignorance and resistance to adopting recommended productivityenhancing measures that go beyond traditional subsistence farming logic (MINECOFIN, 2007 cited by [7]). The rationale of farmers is related to the compatibility of the recommended technology with the existing biophysical environment such as soil, topography, resource and climate.

Interventions that lack systematic consideration of soil fertility variability have been leading to differences in: opinions between actors [8] and problem formulation and solutions sought [11], and hence resulted in poor adoption [3]. For instance, the absence of local participation and non-recognition of indigenous conservation-oriented land use practices in Ethiopia has been reported among reasons for not achieving the desired objectives of soil conservation efforts (Yeraswork, 1998 cited by [12]). In addition, the poor adoption of fertilizer due to recommendation of the same rate of fertilizer on a blanket basis for entire 'Agro-Ecological Zones' (AEZs) but having different soil types was also reported [3]. This highlights the importance of integrating FSK to support site-specific soil management decisions.

Farmers locally have acquired knowledge from generations of experience and experimentation that fit local conditions since they have been interacting with their soils for long time [12-15]. Their knowledge can offer many insights to formulate sustainable management of soils $[13,16,17]$. These days, the value of FSK has received considerable attention by many scientists $[7,12,16,17]$. Its integration with scientific approach is socially acceptable, ecologically sustainable and economically viable [7, 17]; and also it is believed to overcome the shortcomings of scientific intervention while performing under wider ranges $[3,17]$. The FSK is also referred as local, traditional, folk, native or indigenous soil knowledge [7]. The acknowledgement of FSK worldwide has led to a new field of science which is called Ethnopedology $[7,17]$. Ethnopedology as a field of study aims to document and understand local approaches to soil perception, classification, appraisal, use and management [18]. Thus, in order to facilitate communication between researchers and farmers, and potentially improve the likelihood of success of soil fertility management interventions, incorporation of site-specific soil information and knowledge is needed for getting huge benefits.

Findings from different parts of the world such as Ethiopia [8, 12, 19, 20], Kenya [6], Burkina Faso [10], Rwanda [7], Mexico [17], Nepal [21] and Costa Rica [15] highlight that farmers locally have a broad knowledge to describe and classify soils that are relevant for development of soil-specific technologies. The farmers' rationality while classification combines cognitive soil knowledge (e.g., color, texture, soil types, soil suitability) and soil-related practices including land use, crop suitability and soil fertility management [e.g., 7, 15]. In view of that, different scholars suggested the need to incorporate farmers' soil knowledge in the development of holistic soil management approaches [7, 8, 12, 15, 22].

In the complex physiographic conditions like Wolaita [5], tailoring soil fertility management recommendations to specific soil types has been a crucial problem. Few studies in the area reported that farmers have a broader knowledge of their soils $[8,23]$. However, their knowledge and sitespecific soil information are much less studied so as to support the scientific information and objectively interpret the farmers' logic in soil fertility management. Consequently, it affects communication between extension practitioners and farmers to assure soil-specific interventions. It is supposed that the introduction of any soil-related intervention in harmony with the FSK system is likely to increase its relevance and adoption. Thus, the objectives of this study were to identify farmers' soil nomenclature and rationality; to demonstrate how FSK relates to scientifically analyzed soil properties; and to explore the implemented soil management practices and crop performances in selected districts of Wolaita zone, southern Ethiopia.

\section{Methods}

\section{Description of the study area}

The study was conducted in Damot Gale, Damot Sore and Sodo Zuria districts, Wolaita zone, SNNPRS of Ethiopia (Fig. 1), during 2013. The study districts or locally called woredas from Wolaita zone were purposefully selected as they are among the districts where crop production has largely been undertaken. The sites are located between $037^{\circ} 35^{\prime} 30^{\prime \prime}-037^{\circ} 58^{\prime} 36^{\prime \prime} \mathrm{E}$ and $06^{\circ} 57^{\prime} 20^{\prime \prime}-07^{\circ} 04^{\prime} 31^{\prime \prime} \mathrm{N}$. From the total of 82 kebeles (peasant associations) surveyed, 31 were from Damot Gale, 18 from Damot Sore and 33 from Sodo Zuria district. In total, the study area covers about 84,000 hectares (ha) of land.

The 10 years (2003-2013) mean annual precipitation of the study area was about $1355 \mathrm{~mm}$. The area has a bimodal rainfall pattern (Fig. 2) and about 31 and $39 \%$ fall during autumn (March-May) and summer (June-August) seasons, respectively. The mean monthly 


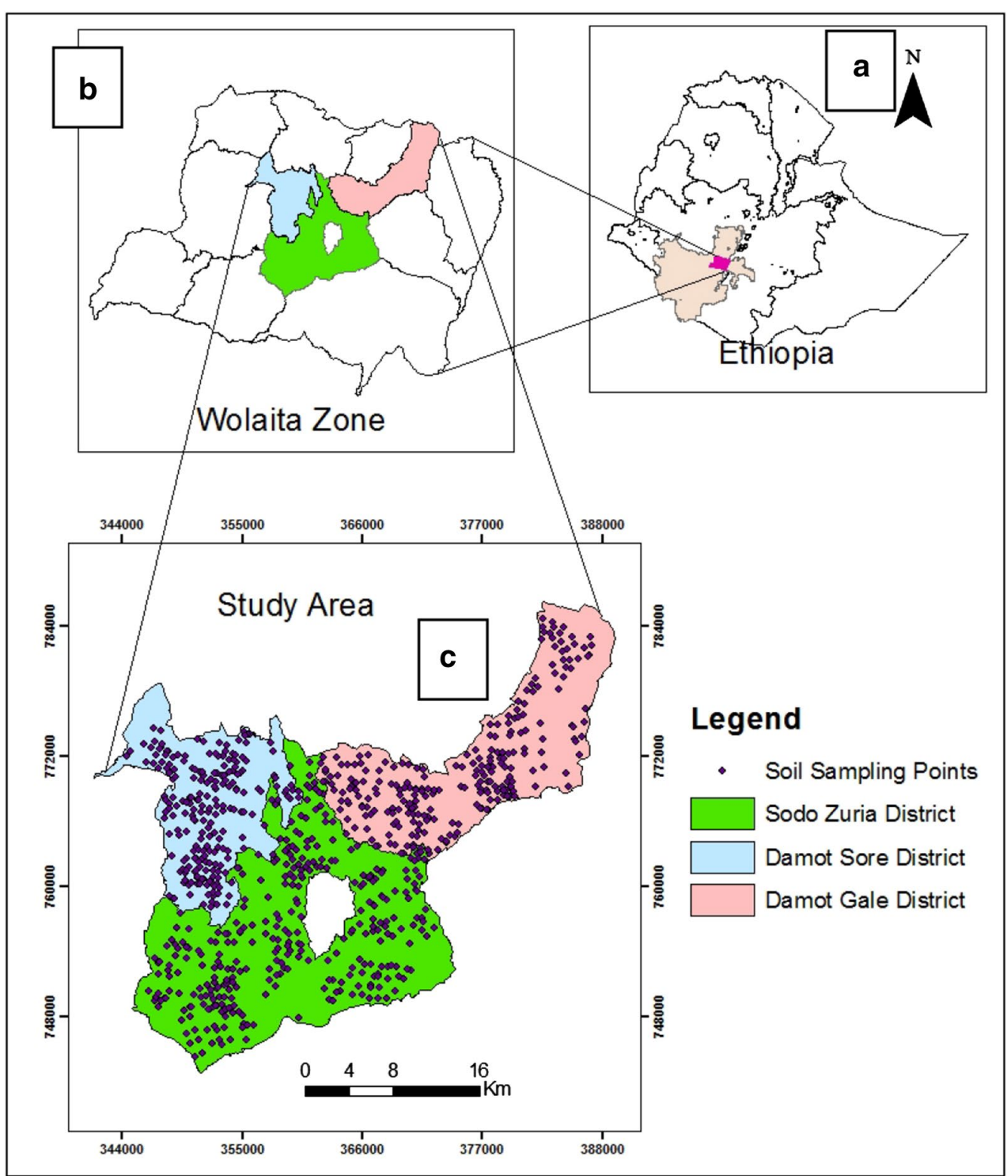

Fig. 1 Location map of SNNPRS in Ethiopia and Wolaita Zone in SNNPRS (A), study districts in Wolaita Zone (B) and soil sampling points in the study areas (C)

temperature for the 10 years (2003-2013) ranges from 17.7 to $21.7^{\circ} \mathrm{C}$ with an average of $19.7^{\circ} \mathrm{C}$ [24].

The elevation of the study districts ranges between 1473 and 2873 meters above sea level (m.a.s.l). As per the traditional agro-ecological zone classification of Ethiopia, the area is predominantly characterized by mid-highland agro-ecology. Besides, small portion of highlands in Damot Gale and Sodo Zuria districts and very small pocket lowland areas in Damot Sore districts is identified. Spatially, out of the total study area, about 0.003,
96 and 3.7\% are found under lowland, mid-highland and highland agro-ecologies, respectively.

Eutric Nitisols associated with Humic Nitisols are the most prevalent soils in Wolaita Zone [25]. These are dark reddish brown soils with deep profiles. Agriculture in the study area is predominantly smallholder mixed subsistence farming and is dominantly rain-fed. Continuous cultivation without any fallow periods coupled with complete removal of crop residues is a common practice on cultivated fields. Farmers use diammonium phosphate 


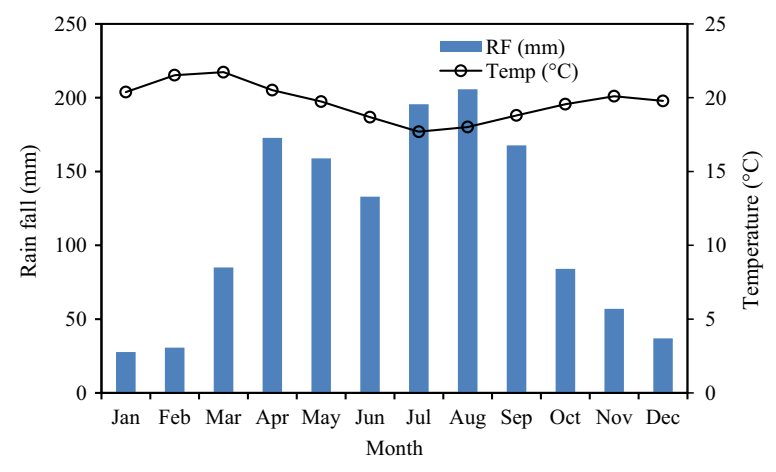

Fig. 2 Ten years (2003-2013) monthly average rainfall and temperature of the study area. National Meteorological Agency [24]

(DAP), urea and farmyard manure (FYM) as sources of fertilizers.

The major crops grown in the study area include tef (Eragrostis tef (Zucc.) Trotter), maize (Zea mays L.), bread wheat (Triticum aestivum L.), haricot bean (Phaseolus vulgaris L.), field pea (Pisum sativum L.), potato (Solanum tuberosum), sweet potato (Ipomea batatas (L) Lam.), taro (Colocasia esculenta (L.) shoot.), enset (Ensete ventricosum (Welw.) chesman) and coffee (Coffea arabica).The vegetation is dominated by eucalyptus trees (Camaldulensis spp.). Remnants of indigenous tree species such as croton (Croton macrostachyus Hochst. ex Rich.), cordia (Cordiaa fricanaLam.), Erythrina spp, podocarpus (Podocarpus falcatus) and Juniperus (Juniperus procera) are also present.

\section{Soil sampling procedure and laboratory analysis Soil sampling procedure}

At the beginning, a preliminary interpretation of the topographic map (scale 1:50,000) obtained from Ethiopian Mapping Authority (EMA) was utilized. Geographical information system (GIS) software (Arc Map version 10) was employed to randomly assign sample collection points. A total of 789 randomly selected agricultural fields (i.e., 243 on Damot Gale, 216 on Damot Sore and 330 on Sodo Zuria) covering all representative land use types were generated for sample and data collection. The samples were randomly distributed at an average distance of 512 meters. During survey work, the pre-defined sample locations were visited in the field and the location was recorded using the GPS (geographical positioning system) receiver (model Garmin GPSMAP 60Cx).

Apart from soil sample collection, soil color, local soil name, land use type, crop type grown, fertilizer use (types and rates) and farmers-estimated crop yield from each field were recorded. Farmers were asked the name of soil color, and it was also described using Munsell soil color chart [26]. Farmers' owning the fields were interviewed about local soil name and fertilizer usage (type and rate) for the existing crops sown at the time of sampling. This helped to explore farmers' rationality to implement soil management practices.

\section{Soil sampling, sample preparation and soil analysis}

Disturbed and undisturbed soil samples were taken from the field using augur and core sampler, respectively. In order to form a composite sample, 10-15 subsamples from each field were collected. The sampling depth was $20 \mathrm{~cm}$ for annual crops such as tef, haricot bean, maize, etc., while it extends up to $50 \mathrm{~cm}$ for perennial crops such as enset and coffee growing fields. From the composited sample, one kilogram $(\mathrm{kg})$ of soil was taken with a labeled soil sample bag.

Sample preparation (drying, grinding and sieving) was conducted at the National Soil Testing Center (NSTC), Addis Ababa, Ethiopia. Particle size distribution (PSD) was analyzed by laser diffraction method using laser scattering particle size distribution analyzer (Horiba-Partica LA-950V2) [27]. Soil bulk density was determined using the core method [28]. Soil pH (1:2 soil/water suspension) was measured with glass electrode (model CP-501) [29]. Available phosphorous (P), available sulfur (S), exchangeable basic cations [calcium $(\mathrm{Ca})$, magnesium $(\mathrm{Mg})$ and potassium $(\mathrm{K})$ ] and extractable micronutrients [iron $(\mathrm{Fe})$, manganese $(\mathrm{Mn})$, boron $(\mathrm{B})$, copper $(\mathrm{Cu})$ and zinc $(\mathrm{Zn})]$ were determined using Mehlich-III multi-nutrient extraction method [30]. The concentration of elements in the supernatant was measured using inductively coupled plasma (ICP) spectrometer.

Mid-infrared diffused reflectance (MIR) spectral analysis was used to determine the amount of soil organic carbon (OC), total nitrogen $(\mathrm{N})$ and cation exchange capacity (CEC). The available soil Mn content was determined using manganese activity index (MnAI) as described by Karltun et al. [31]. Particle size distribution, $\mathrm{pH}, \mathrm{OC}, \mathrm{TN}$ and CEC were analyzed at the National Soil Testing Center (NSTC), Addis Ababa, Ethiopia, whereas $\mathrm{Ca}, \mathrm{Mg}, \mathrm{K}, \mathrm{B}, \mathrm{Cu}, \mathrm{Fe}, \mathrm{Mn}$ and $\mathrm{Zn}$ were analyzed in Altic B.V., Dronten, The Netherlands.

\section{Data analysis}

Descriptive statistics was employed for data analysis. In addition, $F$ tests were also computed. Data analysis was carried out using Microsoft excel and statistical package for social sciences (SPSS) software version 20.

\section{Results and discussion}

\section{Farmer's soil type}

It can be seen from both Fig. 3 and Table 1 that farmers in the present study have a tradition of associating 


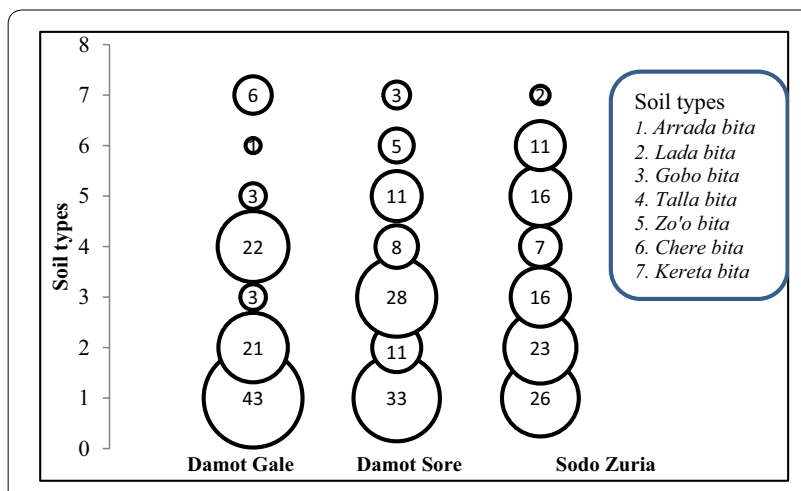

Fig. 3 Farmers soil types for samples collected from studied districts. The size and number of each bubble indicate proportion and percentage considering the number of samples at the district. Sample size for Damot Gale $=243$, Damot Sore $=216$, SodoZuria $=330$ and total $=789$

soil variability with different local soil nomenclatures. Farmers used a holistic approach to recognize, classify and name local soils. The farmers' rationality while classification combines farmers' cognitive knowledge about soils (e.g., its color, permeability, water holding capacity, workability, texture, and fertility) with soil-related practices such as crop suitability, soil fertility management (Table 1). Similarly, the broad criteria of farmers' were also reported by [7, 17]. Farmers identified 12 soil types (Table 1). The naming and classification indicators of most of soil types are relatively homogeneous over large area speaking the same language 'Wolaitia.' Consequently, seven soil types common in the area that account for $99 \%$ samples were identified (Fig. 3). Unlike the standard procedure that groups the soils of the study area as Nitisols [8,25], farmer's soil types are in detail and very diverse. Farmers use the word bita as suffix, an expression in Wolaitia language, that literally means soil.

Among soil types, Arrada bita predominates in proportion followed by Lada bita $>$ Gobo bita $>$ Talla bita $>$ Zo'o bita (Fig. 3). Similarly, the study made by Data [32] indicated that most adult male farmers in Wolaita can name up to eight different soil types, depending on whether they reside in a highland, midland or lowland area. In addition, the study by Pound and Jonfa [23] conducted in the neighboring district (Kindo Koyisha), Wolaita zone, indicated similar soil types such as Kereta, Gobo, Talla, and Chere bita. Generally, the occurrence of soil types varied across landscape positions. Chere bita was common on flat slope positions. Arrada, Gobo and Kereta bita were dominantly found in gentle slopes. Lada, Talla and Zo'o bita, which are prominently regarded as low fertile soils, were located from gentle to hilly slope lands. According to Data and Scoones [8], the greater diversity of soil types identified by farmers in Wolaita derives from a combination of several factors such as landscape positions, variation in soil property (e.g., texture and color most notably) and their effects on crop growth.

Soil color was commonly used indicator among farmers to classify soil. The dominant soil colors were brown, dark reddish brown and reddish brown colors. Farmers locally regarded reddish brown soil as poor in fertility, and darker soils as good fertile soils. They mostly perceived that soils rich in soil organic matter, i.e., fertile soils, have darker color. The uses of color as a descriptor of soils have been reported by different scholars [14, 17 , $19,21,23]$, and the authors stated that farmers' perceived and preferred black soils than red soils.

Farmer's soil fertility knowledge is a function of many variables that are being considered simultaneously, and most of them are interrelated. They locally regarded soil fertility from low to high levels. Summarizing farmers' beliefs, $58 \%$ of the sampled fields were found within dominantly low-fertility category. In terms of workability, the soils vary from easy to difficult to work categories (Table 1). The difference might be attributed to the amount of clay having sticky property and soil moisture content. Hence, soils thought to have high clay content (e.g., Chere, Talla and Kereta bita) become sticky upon wetting, and difficult to plow during dry season cultivation. The rate of water infiltration is critical in the study area as it affects crop growth, crop choice, cropping intensity and management. For this reason, farmers are permanently assessing the degree and distribution of moisture in the soil layers throughout the agricultural cycle [17]. The capacity of soils to permit water movement (permeability) and retain within root zone depends on soil types. According to farmers ranking, soil permeability varies between low (water-retaining soil) and high (percolate and dry fast). For instance, the limitation in Gobo bita is the excessive permeability which makes it more sensitive to water shortage. On the other hand, Chere bita has low permeability, difficult to work (when wet and dry), and used to cultivate crops that adapt to the condition once in a year.

The knowledge of farmers in judging their soils using holistic views, such as soil color, permeability, water holding capacity, workability and soil fertility, has been reported in Ethiopia [19, 20], Burkina Faso [10], Northern Laos [14], western Kenya [6], Nepal [21], Mexico [17] and Rwanda [7].

\section{Farmers' soil types and their properties}

Table 2 presents the soil physicochemical properties, and it shows variation along farmer's soil types. Soil particle size distribution indicated that the clay and silt contents ranged from 35 to $71 \%$ and 19 to $47 \%$, 
Table 1 Farmers' soil types and perceived soil characteristics in studied districts of Wolaita Zone, southern Ethiopia. Source: Survey result (2013)

\begin{tabular}{|c|c|c|c|c|c|c|}
\hline \multirow[t]{2}{*}{ Local soil types ${ }^{a}$} & \multirow{2}{*}{$\begin{array}{l}\text { Approximate con- } \\
\text { notation }\end{array}$} & \multicolumn{5}{|l|}{ Indicators } \\
\hline & & Land unit & Soil color ${ }^{\mathbf{b}}$ & Fertility & Workability & Permeability \\
\hline Arradabita & Fertile soil & $G L$ & $\begin{array}{l}\text { Brown }(42 \%)>\text { reddish } \\
\text { brown }(20 \%)>\text { dark } \\
\text { reddish brown } \\
(17 \%)>\text { gray }(7 \%) \text {, } \\
\text { other brownish }\end{array}$ & Medium-high & Easy to moderate & Optimum \\
\hline Ladabita & Infertile soil & GL to HL & $\begin{array}{l}\text { Brown }=\text { dark reddish } \\
\text { brown (30\% each), } \\
\text { reddish brown }(24 \%), \\
\text { yellowish brown (4\%) }\end{array}$ & Low & Moderate & Moderate-high \\
\hline Gobo bita & Highly permeable soil & $G L$ & $\begin{array}{l}\text { Dark reddish brown } \\
\qquad(42 \%)>\text { reddish } \\
\text { brown }(32 \%)>\text { brown } \\
(20 \%)\end{array}$ & Low > medium & Moderate & High \\
\hline Talla bita & Sticky soil & GL to $H L$ & $\begin{array}{l}\text { Brown }=\text { dark reddish } \\
\text { brown (34\% each), } \\
\text { reddish brown (11\%), } \\
\text { gray }(8 \%)\end{array}$ & Low-medium & $\begin{array}{l}\text { Difficult to work (sticky } \\
\text { when wet and strong } \\
\text { when dry) }\end{array}$ & Low-moderate \\
\hline Zóo bita & Red soil & $\mathrm{GL}$ to $\mathrm{HL}$ & $\begin{array}{l}\text { Dark reddish brown } \\
\qquad(45 \%)>\text { reddish } \\
\text { brown }(36 \%)>\text { brown } \\
(11 \%)\end{array}$ & Low > medium & Moderate & Moderate-high \\
\hline Chere bita & $\begin{array}{l}\text { High-water-retaining } \\
\text { soil }\end{array}$ & $\mathrm{FL}$ & $\begin{array}{l}\text { Gray (55\%), grayish } \\
\text { brown (17\%), brown } \\
\text { (15\%), other gray to } \\
\text { brownish }\end{array}$ & Medium & $\begin{array}{l}\text { Difficult to work (when } \\
\text { wet) }\end{array}$ & $\begin{array}{l}\text { Low (water-retaining } \\
\text { soil) }\end{array}$ \\
\hline Kereta bita & Black soil & FL to GL & $\begin{array}{c}\text { Brown }(44 \%)>\text { reddish } \\
\text { brown }(19 \%), \text { grayish } \\
\text { brown = gray }(11 \%), \\
\text { dark gray }=\text { dark red- } \\
\text { dish brown }(7.4 \%)\end{array}$ & Medium-high & $\begin{array}{l}\text { Difficult to work (when } \\
\text { dry and wet) }\end{array}$ & Moderate \\
\hline Barta bita & $\begin{array}{l}\text { Soil on stony and } \\
\text { eroded land }\end{array}$ & $H L$ & $\begin{array}{l}\text { Brown }>\text { pinkish } \\
\text { brown = very dark } \\
\text { gray }\end{array}$ & Low & Moderate & High \\
\hline Akiaka bita & $\begin{array}{l}\text { A field having both } \\
\text { infertile and perme- } \\
\text { able soils }\end{array}$ & $H L$ & Brown & Medium & Moderate & High \\
\hline Allo bita & $\begin{array}{l}\text { Soil on newly fallowed } \\
\text { land }\end{array}$ & $H L$ & Grayish brown & Low & Moderate & High \\
\hline Dubule bita & $\begin{array}{l}\text { Infertile and perme- } \\
\text { able soil }\end{array}$ & GL to HL & Brown & Low & Moderate & High \\
\hline Goshe bita & $\begin{array}{l}\text { Infertile soil on sloppy } \\
\text { area }\end{array}$ & $H L$ & Brown & Very low & Moderate & Moderate \\
\hline
\end{tabular}

'Bita' literally means soil. Numbers in parenthesis indicate the percentages

$F L$ flat land, $G L$ gentle slope land, $H L$ hilly land

a Farmers soil types that have different fertility levels are in the same soil type (Nitosols)

b Farmers during soil survey indicated color of the soil, but for better explanation the authors used Munsel color chart

respectively. Clay content revealed an increasing trend from Arrada bita to infertile soil types (Lada, Gobo, Zo'o bita), whereas silt showed an opposite relationship. These relationship was significant and best explained by exponential $\left(r^{2}=0.59\right)$ and linear $\left(r^{2}=0.60\right)$ regression for clay and silt particles, respectively. Accordingly, soils identified as infertile by farmers (Lada bita and
Zo'o bita) have clayey texture, while those perceived as medium to high fertile soils (e.g., Arrada bita) have silty clay textural class (Table 2). The variation in soil texture among soil types might be attributed to their occurrence at varying topographic positions, where soils located on gentle to hilly slope lands tend to have clay texture compared to silty texture down the slope [33]. 
Table 2 Mean values of the physicochemical properties of locally classified soils in studied districts of Wolaita zone, southern Ethiopia

\begin{tabular}{|c|c|c|c|c|c|c|c|}
\hline \multirow[t]{2}{*}{ Parameters } & \multicolumn{7}{|c|}{ Farmers soil types } \\
\hline & Arrada bita & Kereta bita & Chere bita & Talla bita & Gobo bita & Zo'o bita & Lada bita \\
\hline Sand (\%) & 15.1 & 17.4 & 14.7 & 13.5 & 11.5 & 9.7 & 14.1 \\
\hline Silt (\%) & 40.0 & 47.2 & 40.5 & 36.1 & 22.4 & 19.2 & 30.7 \\
\hline Clay (\%) & 44.9 & 35.4 & 44.8 & 50.4 & 66.1 & 71.1 & 55.2 \\
\hline Textural class & Silty clay & Silty clay loam & Silty clay & Clay & Clay & Clay & Clay \\
\hline Bulk density $\left(\mathrm{g} \mathrm{cm}^{-3}\right)$ & 1.1 & 1.1 & 1.1 & 1.2 & 1.2 & 1.2 & 1.2 \\
\hline $\mathrm{pH}-\mathrm{H}_{2} \mathrm{O}$ & 6.4 & 6.2 & 5.8 & 6.2 & 5.9 & 5.6 & 6.0 \\
\hline OC (\%) & 2.2 & 1.9 & 1.8 & 1.6 & 2.2 & 2.2 & 1.7 \\
\hline TN (\%) & 0.2 & 0.1 & 0.1 & 0.1 & 0.2 & 0.2 & 0.1 \\
\hline$P\left(\mathrm{mg} \mathrm{kg}^{-1}\right)$ & 21.0 & 7.6 & 7.3 & 5.3 & 5.7 & 3.0 & 3.3 \\
\hline $\mathrm{Ca}\left(\mathrm{Cmol}_{\mathrm{C}} \mathrm{kg}^{-1}\right)$ & 9.9 & 8.7 & 7.8 & 8.9 & 6.5 & 5.5 & 6.3 \\
\hline $\mathrm{K}\left(\mathrm{Cmol}_{\mathrm{C}} \mathrm{kg}^{-1}\right)$ & 1.9 & 1.0 & 0.6 & 1.2 & 1.1 & 0.9 & 0.9 \\
\hline $\mathrm{Mg}\left(\mathrm{Cmol}_{\mathrm{C}} \mathrm{kg}^{-1}\right)$ & 2.2 & 1.6 & 1.6 & 2.3 & 1.9 & 1.7 & 1.7 \\
\hline $\mathrm{S}\left(\mathrm{mg} \mathrm{kg}^{-1}\right)$ & 10.4 & 10.5 & 10.0 & 9.9 & 11.5 & 13.5 & 10.8 \\
\hline $\mathrm{B}\left(\mathrm{mg} \mathrm{kg}^{-1}\right)$ & 0.7 & 0.4 & 0.4 & 0.5 & 0.5 & 0.5 & 0.4 \\
\hline $\mathrm{Cu}\left(\mathrm{mg} \mathrm{kg}^{-1}\right)$ & 0.7 & 0.6 & 0.6 & 0.4 & 0.6 & 0.4 & 0.4 \\
\hline $\mathrm{Fe}\left(\mathrm{mg} \mathrm{kg}^{-1}\right)$ & 121.1 & 140.5 & 234.7 & 134.9 & 114.7 & 106.6 & 118.3 \\
\hline $\mathrm{Mn}\left(\mathrm{mg} \mathrm{kg}^{-1}\right)$ & 159.7 & 125.9 & 89.9 & 141.6 & 157.0 & 137.5 & 136.4 \\
\hline $\mathrm{MnAl}\left(\mathrm{mg} \mathrm{kg}^{-1}\right)$ & 602.7 & 480.0 & 351.2 & 538.1 & 601.2 & 532.4 & 522.5 \\
\hline $\mathrm{Zn}\left(\mathrm{mg} \mathrm{kg}^{-1}\right)$ & 13.3 & 9.8 & 4.1 & 6.5 & 7.8 & 5.8 & 6.3 \\
\hline TEB $\left(\mathrm{Cmol}_{c} \mathrm{~kg}^{-1}\right)$ & 14.7 & 12.1 & 10.8 & 13.2 & 10.3 & 8.9 & 9.7 \\
\hline $\mathrm{CEC}\left(\mathrm{Cmol}_{\mathrm{C}} \mathrm{kg}^{-1}\right)$ & 23.0 & 19.6 & 17.8 & 22.1 & 20.3 & 19.6 & 19.1 \\
\hline
\end{tabular}

Soil bulk density was between 1.1 and $1.2 \mathrm{~g} \mathrm{~cm}^{-3}$ where the lowest and highest values were for fertile and infertile soil classes, respectively. It was also noted that bulk density showed a declining trend as it goes from Arrada bita to infertile soil types (Lada, Gobo, Zo'o bita). The relationship was significant and best explained by polynomial regression $\left(r^{2}=0.78\right)$. The difference in variation could be associated with soil textural classes [33]. However, the mean value was found satisfactory for plant growth [34].

The mean soil $\mathrm{pH}\left(\mathrm{H}_{2} \mathrm{O}\right)$ varied from 5.6 (Zo'o bita) to 6.4 (Arrada bita). Variations in soil management practices among soil types might contribute to the observed $\mathrm{pH}$ values. Relatively, the higher organic fertilizer and home-left residue application on Arrada bita ought to contribute to the higher $\mathrm{pH}$ compared to Zo'o bita (Table 2) which is mostly subjected to complete crop residue removal and inorganic fertilizer use. Soil pH showed a declining trend from Arrada bita toward infertile soil types (Lada, Gobo, Zo'o bita). This trend was explained by polynomial regression $\left(r^{2}=0.54\right)$. Similarly, Saito et al. [14] reported that soils farmers described as fertile had the higher $\mathrm{pH}$ than the other soils. However, the mean $\mathrm{pH}$ value of soil types was rated under moderately acidic category (5.6-6.5) [35].
The soil organic carbon (OC) content was between 1.6\% (Talla bita) and 2.2\% (Arrada, Gobo and Zo'o bita). Regardless of the values, the soil types were grouped under very low $(<2 \%)$ and low $(2-4 \%)$ [36]. This could indicate how the soil types in the study area have been exposed to intensive cultivations. Total nitrogen (TN) varies from 0.1 to $0.2 \%$ (Table 2). Generally, soils perceived to be fertile (e.g., Arrada bita) and infertile (e.g., Lada bita) by farmers recorded the highest and least values, respectively. Likewise, soils types which are difficult to plow and high-water-retaining soil (e.g., Talla, Gobo and Chere bita) had the least TN value which could be ascribed to high uptake and susceptibility of $\mathrm{N}$ to different losses. Asongwe et al. [37] stated that farm-specific practices might have influenced mineralization where areas characterized by rapid mineralization would result in high nitrogen losses. The soil TN was under low (0.1$0.2 \%$ ) status [36]. Total soil $\mathrm{N}$ is normally considered a rather poor indicator of plant-available N. However, it is believed that TN becomes a good proxy for soil $\mathrm{N}$ mineralization capacity [12].

Available P concentration of soil types ranged between 3 and $21 \mathrm{mg} \mathrm{kg}^{-1}$ (Table 2). The soil type having higher soil pH and OC (i.e., Arrada bita) recorded the highest value compared to all other soils that had between 3 
and $8 \mathrm{mg} \mathrm{kg}^{-1}$ (Table 2). This relationship was significant and best described by exponential regression $\left(r^{2}=0.83\right)$. However, irrespective of numerical differences, all locally identified soils showed P concentration below the critical level $\left(30 \mathrm{mg} \mathrm{kg}^{-1}\right)$ suggested for Ethiopian soils [35]. The lower P content might be ascribed to the combined effects of intensive cultivation, lower $\mathrm{P}$ and organic fertilizer application, and lower $\mathrm{pH}$ values. Lower $\mathrm{P}$ content on cultivated soils was also reported in the literature [4, $5,37-39]$.

The result regarding exchangeable bases revealed differences among soil types (Table 2). The cation exchange site of soil types was mainly occupied by $\mathrm{Ca}>\mathrm{Mg}>\mathrm{K}$. The concentration of bases in the exchange complex ranged from 9 to $15 \mathrm{Cmol}_{\mathrm{c}} \mathrm{kg}^{-1}$ (Table 2). The highest and least values were recorded from Arrada bita and Lada bita, respectively. Total exchangeable bases of soil types seem decreased from Arrada bita to Lada bita. This relationship between soil types and exchangeable bases was significant and best described by logarithmic regression $\left(r^{2}=0.71\right)$. Mostly, Arrada bita is located close to homestead areas where it received ash, household refuse and manure. These practices could result in the higher base status in Arrada bita instead of Lada bita where continuous uptake without nutrient application and leaching is more [33,37]. On the other hand, available $\mathrm{S}$ status of soil types was found under narrow ranges $\left(10-13.5 \mathrm{mg} \mathrm{kg}^{-1}\right)$ which is below the critical levels used for Ethiopian soils $\left(20 \mathrm{mg} \mathrm{kg}^{-1}\right)$ [35]. The lower $\mathrm{S}$ in all soil types could be linked to lower soil OC, crop uptake and non-use of S fertilizers. In Ethiopia, different researchers also reported the lower available $\mathrm{S}$ content in cultivated soils $[4,5,35,40]$.

There existed variability of micronutrient contents of soil types (Table 2). Boron and $\mathrm{Cu}$ concentrations varied from 0.4 to $0.7 \mathrm{mg} \mathrm{kg}^{-1}$ in which the higher content was recorded from fertile soil (e.g., Arrada bita), while the least on infertile soil (e.g., Lada bita). In the meantime, the relationship between $\mathrm{Cu}$ and soil types was significantly predicted by a positive linear regression $\left(r^{2}=0.64\right)$. The coefficient of regression for B with soil types was not significant but explained by logarithmic regression $\left(r^{2}=0.33\right)$. Nonetheless, irrespective of the soil types, their status was found below critical levels suggested for Ethiopian soils, i.e., $0.8 \mathrm{mg} \mathrm{kg}^{-1}$ for B and $0.9 \mathrm{mg} \mathrm{kg}^{-1}$ for $\mathrm{Cu}$ [35]. On the other hand, Fe, Mn and $\mathrm{Zn}$ in all soil types were found above the critical level of $\mathrm{Fe}\left(80 \mathrm{mg} \mathrm{kg}^{-1}\right)$, Mn $\left(25 \mathrm{mg} \mathrm{kg}^{-1}\right)$ and $\mathrm{Zn}\left(1.5 \mathrm{mg} \mathrm{kg}^{-1}\right)$ [35].

The CEC of the soil varied from 18 to $23 \mathrm{Cmol}_{\mathrm{c}} \mathrm{kg}^{-1}$. The higher value was obtained from Arrada bita, and the least was on water-retaining soil (Chere bita) and infertile soil (e.g., Lada bita). According to Landon [36], soil types fall under medium CEC category $\left(15-25 \mathrm{Cmol}_{\mathrm{c}} \mathrm{kg}^{-1}\right)$, implying that they have moderate potential to hold nutrients against leaching losses. The finding reported by Fanuel [33] in the study area indicated that source of charges in the $\mathrm{CEC}$ is $\mathrm{pH}$ dependent. It is thus imperative to manage and raise the soil $\mathrm{pH}$ in order to increase their potential [37]. This is witnessed on Arrada bita which received relatively better soil management and higher $\mathrm{pH}$ (6.4) and in turn owes higher CEC than the other soil types. Correspondingly, higher CEC values on soils identified as fertile by farmers' compared to soils perceived as non-fertile soil were also reported [14].

In general, the farmers' logic demonstrated an association with scientific knowledge on most of measured soil physical and chemical properties when looking the trends. This suggests farmers' ability to differentiate soil fertility variability. This is consistent with $[7,12,17,21]$ who observed that FSK has a good agreement with scientifically measured soil properties. Despite farmers' knowledge to understand soil variability of their field and exploit any soil fertility differences of their field, ratings using chemical properties identified nutrient limitation. This is demonstrating that scientific disciplines such as soil chemistry and soil biology are important tools to upgrade the FSK system [7]. Hence, complementing FSK with scientific approaches (chemical soil properties) in the study area is important to better recognize the biophysical environment, interpret farmers' rationality, establish robust relationship between the approaches, communicate with farmers in a friendly way and potentially improve the likelihood of success of soil fertility management interventions.

\section{Farmers' soil fertility management strategies}

Farmers use diammonium phosphate (DAP), urea and farmyard manure (FYM) as sources of fertilizers. The crops on which inputs are applied in the area include Tef, maize, wheat, haricot bean, potato, sweet potato, taro, enset and coffee. Farmers preferably apply FYM or homeleft wastes to enset, coffee and root and tubers crops, while mineral fertilizers are used for tef, maize, wheat, haricot bean and potato. Fertilizer-allocation practices by farmers in Wolaita area specifically to the study area are also briefly indicated in [5].

Mean application rate of DAP and FYM significantly varied among farmers' soil types (Table 3). Farmers applied the least $\left(23 \mathrm{~kg} \mathrm{ha}^{-1}\right)$ and highest $\left(50.6 \mathrm{~kg} \mathrm{ha}^{-1}\right)$ amount of DAP fertilizer on fertile soil (Arrada bita) and waterlogged (Chere bita), respectively, in which the maximum amount was followed by infertile soil (Zo'o bita), i.e., $45.3 \mathrm{~kg} \mathrm{ha}^{-1}$. The use of inorganic fertilizer was higher on less fertile soil types than on fertile soils. The application of urea fertilizer was found nonsignificant 
Table 3 Soil fertility management on locally classified soils in studied districts of Wolaita zone, southern Ethiopia

\begin{tabular}{|c|c|c|c|c|c|c|c|c|c|}
\hline \multirow[t]{2}{*}{ Parameters } & \multicolumn{9}{|c|}{ Farmers soil types } \\
\hline & Arrada bita & Kereta bita & Chere bita & Talla bita & Gobo bita & Zo'o bita & Lada bita & $F_{\text {value }}$ & Sig. \\
\hline $\operatorname{DAP}\left(\mathrm{kg} \mathrm{ha}^{-1}\right)$ & 23.3 & 43.0 & 50.6 & 33.0 & 43.2 & 45.3 & 39.2 & 9.6 & 0.000 \\
\hline Urea $\left(\mathrm{kg} \mathrm{ha}^{-1}\right)$ & 7.02 & 4.6 & 3.8 & 8.4 & 8.9 & 6.5 & 7.08 & 0.4 & 0.880 \\
\hline $\mathrm{FYM}\left(\mathrm{t} \mathrm{ha}^{-1}\right)$ & 1.7 & 0.7 & 0.6 & 0.23 & 0.5 & 0.3 & 0.09 & 19.4 & 0.000 \\
\hline
\end{tabular}

DAP diammonium phosphate, FYM farm yard manure

among soil types. Overall, urea was applied at very small amount ranging between 4 and $10 \mathrm{~kg} \mathrm{ha}^{-1}$. The opposite fertilization trend from inorganic fertilizer was observed on FYM. The amount varied from 0.1 to $1.7 \mathrm{t} \mathrm{ha}^{-1}$ (Table 3). Arrada bita received the highest FYM, while the least amount was recorded on Lada bita.

The present findings demonstrated that farmers understand their soil and allocate the crop and scarce fertilizer knowingly. Farmers' logic of soil fertility management has shown an observable relationship with fertilizer application. The relationship was best described by a polynomial function. It was found that as soil fertility level of farmers soil types was declining, the amount of DAP applied to the soil was increasing $\left(r^{2}=0.61\right)$ (Fig. 4). On the other hand, the opposite was noticed for FYM $\left(r^{2}=0.85\right)$ application (Fig. 5).

Farmers in the study area mostly grow perennial and vegetable crops on fertile soils using FYM. When asked reasons for the higher organic fertilizer on Arrada bita, farmers indicate that the better crop response, proximity of garden fields to home, the limited availability of homeleft refuses and FYM, and type of crops grown around home were factors making them allocate more organic residues to Arrada bita. For farmers, organic matter is clearly the main factor to sustain soil fertility, and soils with organic matter in the topsoil are potentially of good agricultural quality [17]. Conversely, farmers use high

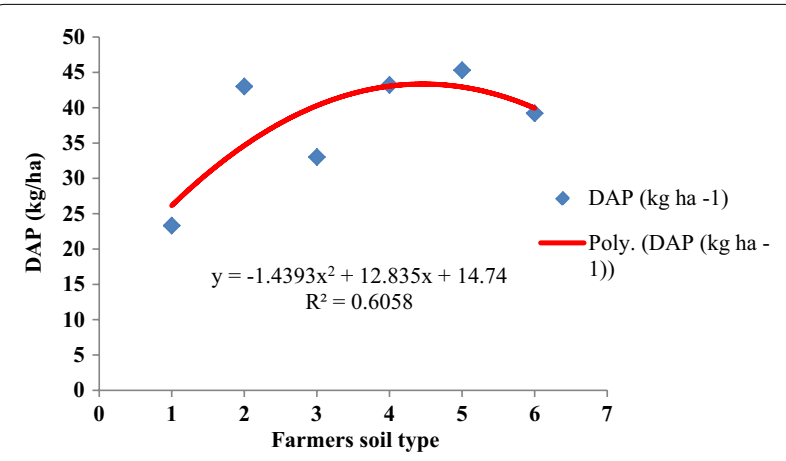

Fig. 4 Relationship between farmers soil type and DAP fertilizer application. Note: 1. Arrada bita, 2. Kereta bita, 3. Talla bita, 4. Gobo bita, 5. Zo'o bita, 6. Lada bita, 7. Chere bita

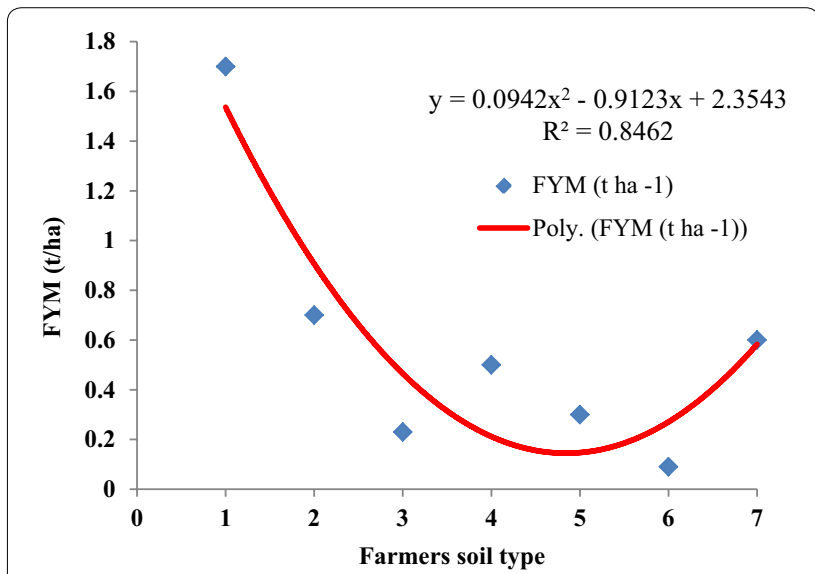

Fig. 5 Relationship between farmers' soil type and FYM application. Note: 1. Arrada bita, 2. Kereta bita, 3. Talla bita, 4. Gobo bita, 5. Zo'o bita, 6. Lada bita, 7. Chere bita

rates of inorganic fertilizers for annual grain crops that are grown on distant fields and less fertile soils. This finding agrees with previous studies in Wolaita [33, 41, 42]. Furthermore, the experience of Rwandan farmers to apply FYM on best soils than on other soil types by realizing best crop responses was reported by Rushemuka et al. [7].

\section{Farmers soil types and their productivity}

Data regarding crop responses among farmers' soil types demonstrated significant differences (Table 4). Soil type perceived as fertile (Arrada bita) demonstrated comparative grain yield (maize and haricot bean) advantage over infertile soils (e.g., Lada bita, Zo'o bita) and higherwater-retaining soil (i.e., Chere bita) (Table 4). The yield of maize in Arrada bita without fertilizer application varied from 0.2 to $1.6 \mathrm{t} \mathrm{ha}^{-1}$, whereas it was between 2.0 and $5.0 \mathrm{tha}^{-1}$ when it was managed with fertilizer. The maize yield in Lada bita, without fertilizer ranged from 0.2 to $1.2 \mathrm{t} \mathrm{ha}^{-1}$, and it varied from 1.0 and $3.0 \mathrm{t} \mathrm{ha}^{-1}$ when fertilized. In the present study, grain yield was declining with a decrease in the fertility level of farmers' soil types (Figs. 6, 7). The grain yield-soil type relationship was best described by a polynomial function with $r^{2}=0.6$ and 
Table 4 Average crop productivity on locally classified soils in studied districts of Wolaita zone, southern Ethiopia

\begin{tabular}{|c|c|c|c|c|c|c|c|c|c|}
\hline \multirow[t]{2}{*}{ Parameters } & \multicolumn{9}{|c|}{ Farmers soil types } \\
\hline & Arrada bita & Kereta bita & Chere bita & Talla bita & Gobo bita & Zo'o bita & Lada bita & $F_{\text {value }}$ & Sig. \\
\hline Maize (W/O) $\left(\mathrm{tha}^{-1}\right)$ & 0.66 & 0.42 & 0.10 & 0.56 & 0.46 & 0.34 & 0.55 & 5.7 & 0.000 \\
\hline Maize (with) (t ha-1) & 2.28 & 1.88 & 1.33 & 2.02 & 1.91 & 1.82 & 1.99 & 2.2 & 0.040 \\
\hline Haricot bean (W/O) $\left(\mathrm{t} \mathrm{ha}^{-1}\right)$ & 0.42 & 0.34 & 0.30 & 0.29 & 0.36 & 0.24 & 0.28 & 10.2 & 0.000 \\
\hline Haricot bean (with) $\left(\mathrm{t} \mathrm{ha}^{-1}\right)$ & 1.28 & 1.15 & 1.10 & 0.97 & 1.21 & 0.98 & 1.02 & 7.4 & 0.000 \\
\hline $\operatorname{Tef}(\mathrm{W} / \mathrm{O})\left(\mathrm{t} \mathrm{ha} \mathrm{C}^{-1}\right)$ & 0.19 & 0.23 & 0.13 & 0.15 & 0.16 & 0.13 & 0.13 & 1.2 & 0.320 \\
\hline Tef (with) (t ha ${ }^{-1}$ ) & 0.73 & 0.65 & 0.70 & 0.66 & 0.74 & 0.63 & 0.70 & 0.8 & 0.56 \\
\hline Sweet potato $(\mathrm{W} / \mathrm{O})\left(\mathrm{t} \mathrm{ha}^{-1}\right)$ & 4.9 & - & - & 5.5 & 4.5 & 4.5 & 4.0 & 0.32 & 0.90 \\
\hline Sweet potato (with) $\left(\mathrm{t} \mathrm{ha}^{-1}\right)$ & 11.1 & - & - & 15.5 & 10.1 & 9.3 & 10.1 & 3.0 & 0.03 \\
\hline
\end{tabular}

$\mathrm{W} / \mathrm{O}=$ without fertilizer application; with $=$ with fertilizer application

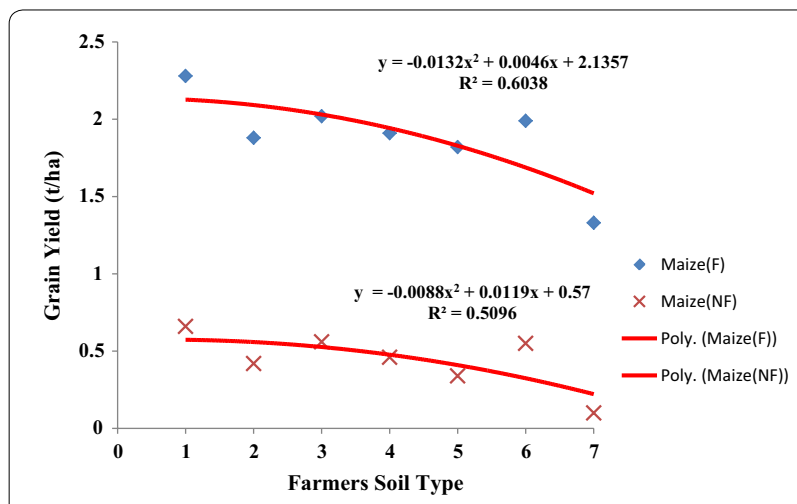

Fig. 6 Relationship between farmers soil type and grain yield of maize. Note: 1. Arrada bita, 2. Kereta bita, 3. Talla bita, 4. Gobo bita, 5. Zo'o bita, 6. Lada bita, 7. Chere bita. F fertilized field by farmers, NF non-fertilized

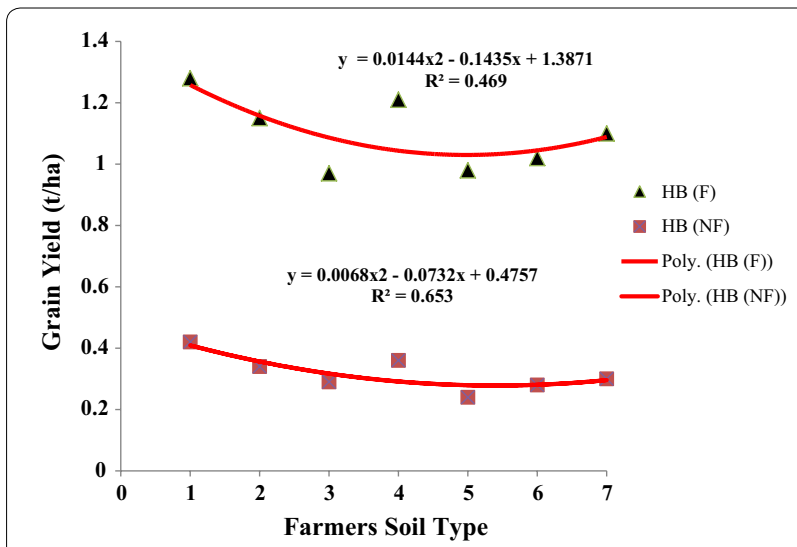

Fig. 7 Relationship between farmers soil type and grain yield of haricot bean. Note: 1. Arrada bita, 2. Kereta bita, 3. Talla bita, 4. Gobo bita, 5. Zo'o bita, 6. Lada bita, 7. Chere bita. F fertilized field by farmers, NF non-fertilized
0.51 under fertilized maize and haricot bean, respectively. In addition, in unfertilized maize and haricot bean, the regression coefficient $\left(r^{2}\right)$ was 0.47 and 0.65 for maize and haricot bean, respectively.

The presence of organic matter in the soil is considered critical for crop performance. A higher yield from fertile soil (e.g., Arrada bita) compared to infertile soil types (e.g., Lada bita, Zo'o bita) could be attributed to relatively higher FYM application and soil properties. In agreement, Rushemuka et al. [7] reported that the favorable response of good soils to FYM application was attributed to supply of soil nutrients. Additionally, the positive impacts of soil organic matter in storing and supplying of nutrients were also described [43-45]. Furthermore, a significantly higher mean yield of rice from black soils (i.e., perceived as fertile by farmers) compared to other soil types was stated [14]. On the other hand, remarkably low yield in Chere bita could be related to high-waterretaining characteristics of the soil.

Yet, farmers in the study area are getting very low yield compared to yield reported from research station in Ethiopia [46] such as maize $\left(12 \mathrm{t} \mathrm{ha}^{-1}\right)$, teff $\left(3.4 \mathrm{t} \mathrm{ha}^{-1}\right)$, haricot bean $\left(4 \mathrm{tha}^{-1}\right)$ and potato $\left(6.5 \mathrm{tha}^{-1}\right)$. The yield gap is emanated from very poor crop residue maintenance, inadequate compensation of plant nutrients and continuous cropping $[4,5]$. Consequently, it resulted in the presence of multi-nutrient deficiencies including $\mathrm{N}, \mathrm{P}, \mathrm{S}$, $\mathrm{B}$ and $\mathrm{Cu}$. Hence, proper practices leading to soil fertility enhancement are mandatory to generate better yields.

\section{Conclusions}

The objectives of this study were to identify farmers' soil nomenclature and their rationality; to demonstrate how farmers' soil knowledge relates to scientifically analyzed soil properties; and to explore the implemented soilspecific fertility management practices. Results from this study have shown that farmers' soil nomenclature 
is broad and often based more on observation and crop responses. Most of the soil types identified by farmers' are common over large area speaking the same language, implying that a venue for developing crop--soil-specific technology. Moreover, farmers' soil types have also shown an association with scientific knowledge, signifying that their knowledge is relevant for site-specific soil management.

Fertilizer use strategy of farmers' differs with soil types and crops. They prefer to apply organic fertilizers on fertile soils (Arrada bita) because an important food security crops such as enset and root and tubers are growing; proximity of the soil type to the source (i.e., home) and better crop yield. On poor fertility but input-responsive soil types (e.g., Lada and Zo'o bita) where crops such as maize, beans and other annual crops are growing, farmers apply chemical fertilizers. Farmers' rationality is also demonstrated on crop responses. They noted better crop yield from fertile soils than from the others. When asked for reasons, farmers indicate that soils managed with organic materials are conducive for crops than those managed with chemical fertilizers. It was concluded that farmers' soil knowledge is rational and specifically addresses farm soil variability occurring over short distances. Nevertheless, they are not capable of identifying yield-limiting nutrients. Hence, supplementing their knowledge with scientific soil information is recognized. Furthermore, systematic investigation is suggested to develop rational communication about soil and improve the success of soil fertility management interventions.

\section{Authors' contributions}

FL collected, analyzed and interpreted the data. KK and TM helped to draft the manuscript. All authors read and approved the final manuscript.

\section{Author details}

1 Department of Plant Science, College of Agriculture, Wolaita Sodo University, Wolaita Sodo, Ethiopia. ${ }^{2}$ School of Natural Resources Management and Environmental Science, Haramaya University, Harar, Ethiopia. ${ }^{3}$ Agricultural Transformation Agency (ATA), Addis Ababa, Ethiopia.

\section{Acknowledgements \\ We would like to thank Ministry of Education (MOE) for the scholarship and the Ethiopian Soil Information System (EthioSIS) at the Agricultural Trans- formation Agency (ATA) for financial support. We are very grateful to all assistances, knowledge and experiences we have received from the farmers in Damot Gale, Damot Sore and Sodo Zuria districts. Our acknowledgment also goes to anonymous reviewers for their critical evaluation and constructive comments. The appreciation further extended to anonymous reviewers for sharing us their time and valuable comments.}

\section{Competing interests}

The authors declare that they have no competing interests.

\section{Availability of data and materials}

We declare that the data and materials presented in this manuscript can be made available as per the editorial policy of the journal.

\section{Consent for publication}

All data and information are generated and organized by the authors.
Ethics approval and consent to participate Not applicable to this manuscript.

\section{Ethical approval}

Not applicable to this manuscript.

Funding

This research was conducted with the financial support of Ethiopian Soil Information System (EthioSIS) at the Agricultural Transformation Agency (ATA).

\section{Publisher's Note}

Springer Nature remains neutral with regard to jurisdictional claims in published maps and institutional affiliations.

Received: 12 July 2017 Accepted: 8 September 2017

Published online: 27 September 2017

\section{References}

1. Rosemary F, Vitharana UWA, Indraratne SP, Weerasooriya R, Mishra U. Exploring the spatial variability of soil properties in an Alfisol soil catena. Catena. 2017;150:53-61.

2. Guan F, Xia M, Tang X, Fan S. Spatial variability of soil nitrogen, phosphorus and potassium contents In Moso bamboo forests in Yong'an City, China. Catena. 2017;150:161-72.

3. Giller KE, Tittonell P, Rufunio MC, van Wijk MT, Zingore S, Mapfumo P, Adjei-Nsiah $\mathrm{S}$, et al. Communicating complexity, integrated assessment of trade-offs concerning soil fertility management within African farming systems to support innovation and development. Agric Syst. 2011:104:191-203.

4. Laekemariam F, Kibret K, Mamo T, Gebrekidan H. Soil-plant nutrient status and their relations in maize-growing fields of Wolaita Zone, southern Ethiopia. Commun Soil Sci Plant Anal. 2016;47(11):1343-56. doi:10.1080/0 0103624.2016.1166378.

5. Laekemariam F, Kibret K, Mamo T, Karltun E, Gebrekidan H. Physiographic characteristics of agricultural lands and farmers' soil fertility management practices in Wolaita zone, southern Ethiopia. Environ Syst Res. 2016:5(24):1-16.

6. Tittonell P, Vanlauwe B, Leffelaar PA, Shepherd KD, Giller KE. Exploring diversity in soil fertility management of smallholder farms in western Kenya II. Within-farm variability in resource allocation, nutrient flows and soil fertility status. Agric Ecosyst Environ. 2005;1 10:166-84.

7. Rushemuka NP, Bizozab RA, Mowo JG, Bock L. Farmers'soil knowledge for effective participatory integrated watershed management in Rwanda: toward soil-specific fertility management and farmers'judgmental fertilizer use. Agr Ecosyst Environ. 2014;183:145-59.

8. Data D, Scoones I. Networks of knowledge: how farmers and scientists understand soils and their fertility. A case study from Ethiopia. Oxf Dev Stud. 2003;31(4):461-78.

9. Corbeels M, Shiferaw A, Haile M. Farmers'knowledge of soil fertility and local management strategies in Tigray, Ethiopia. Manag Afr Soils. 2000;10:11-23.

10. Niemeijer D, Mazzucato V. Moving beyond indigenous soil taxonomies: local theories of soils for sustainable development. Geoderma. 2003; 111:403-24

11. Gray LC, Morant P. Reconciling indigenous knowledge with scientific assessment of soil fertility changes in southwestern Burkina Faso. Geoderma. 2003;111:425-37.

12. Karltun $\mathrm{E}$, Lemenih $\mathrm{M}$, Tolera M. Comparing farmers' perception of soi fertility change with soil properties and crop performance in Beseku, Ethiopia. Land Degrad Dev. 2013;24:228-35.

13. Barrios E, Trejo MT. Implications of local soil knowledge for integrated soil management in Latin America. Geoderma. 2003;111:217-31.

14. Saito K, Linquist B, Keobualapha B, Shiraiwa T, Horie T. Farmers' knowledge of soils in relation to cropping practices: a case study of farmers in upland rice based slash-and-burn systems of northern Laos. Geoderma. 2006;136:64-74. 
15. Winowiecki LA, Whelan MP, McDaniel PA, Villalobos M, Somarriba E. Local soil knowledge and its use in crop allocation: implications for landscapescale agricultural production and conservation efforts in Talamanca, Costa Rica. Agric For Fish. 2014;3(2):93-101.

16. Payton RW, Barr JJF, Martin A, Silitoe P, Deckers JF, Gowing JW, Hatibu N, Naseem SB, Tenywa M, Zuberi MI. Contrasting approaches to integrating indigenous knowledge about soils and scientific soil survey in eastern Africa and Bangladesh. Geoderma. 2003;111:355-86.

17. Barrera-Bassols N, Zinck JA, Van Ranst E. Local soil classification and comparison of indigenous and technical soil maps in a Mesoamerican community using spatial analysis. Geoderma. 2006;135:140-62

18. Barrera-Bassols N, Zinck JA. Ethnopedology: a worldview on the soil knowledge of local people. Geoderma. 2003;111(3-4):171-95.

19. Haileslassie A, Priess JA, Veldkamp E, Lesschen JP. Smallholders' soil fertility management in the central highlands of Ethiopia. Implications for nutrient stocks, balances and sustainability of agro ecosystems. Nutr Cycl Agro Ecosyst. 2006;75:135-46.

20. Abera Y, Belachew T. Local perceptions of soil fertility management in southeastern Ethiopia. Int Res J Agric Sci Soil Sci. 2011;1:064-9.

21. Desbiez A, Matthews R, Tripathi B, Jones JE. Perceptions and assessment of soil fertility by farmers in the mid-hills of Nepal. Agric Ecol Environ. 2004;103:191-206.

22. Barrios E, Delve RJ, Bekunda M, Mowo J, Agunda J, Ramisch J, Trejo MT, Thomas RJ. Indicators of soil quality: a South-South development of a methodological guide for linking local and technical knowledge. Geoderma. 2006;135:248-59.

23. Pound B, Jonfa E. Policy and research series, soil fertility practices in Wolaita Zone, southern Ethiopia: learning from farmers. Hook: Farm Africa, Waterside Press; 2005.

24. NMA (National Meteorological Agency). National meteorological agency. Awassa: Hawassa Branch; 2013.

25. Beshah T. Understanding farmers: explaining soil and water conservation in Konso, Wolaita, and Wollo, Ethiopia. Ph.D. Thesis, Wageningen University and Research Center, The Netherlands. 2003.

26. Munsell Color Company (Baltimore). Munsell soil color charts. Baltimore, Maryland: Munsell Color; 2000.

27. Stefano C, Ferro DV, Mirabile S. Comparison between grain size analysis using laser diffraction and sedimentation methods. Biosyst Eng. 2010;106:205-15.

28. Anderson JM, Ingram JSI. Tropical soil biology and fertility. A handbook of methods. 2nd ed. Wallingford: CAB International; 1993. p. 221.

29. Mylavarapu R. UF/IFAS extension soil testing laboratory (ESTL) analytical procedures and training manual. Gainesville: Circular 1248, Soil and Water Science Department, Florida Cooperative Extension Service, Institute of Food and Agricultural Sciences, University of Florida; 2009.

30. Mehlich A. Mehlich III soil test extractant: a modification of Mehlich II extractant. Commun Soil Sci Plant Anal. 1984;15:1409-16.

31. Karltun E, Tekalign M, Taye B, Sam G, Selamyihun K. Towards improved fertilizer recommendations in Ethiopia-nutrient indices for categorization of fertilizer blends from EthioSISworeda soil inventory data. A discussion paper. Ethiopian Soil Information System (EthioSIS). June, 2013, Addis Abeba, Ethiopia. 2013
32. Data D. Soil Fertility Management in Wolayta, southern Ethiopia. An Anthropological Investigation, FRP Technical Pamphlet, 14 Farmers' Research Project, FARM-Africa, Addis Ababa, Ethiopia. 1996.

33. Fanuel L. Soil spatial variability analysis, fertility mapping and soil plant nutrient relations in Wolaita Zone, southern Ethiopia. Ph.D. dissertation. Submitted to Graduate School of Haramaya University, Ethiopia. 2015. P. 155.

34. Hazelton P, Murphy B. Interpreting soil test results. What do all the numbers mean?. Clayton: CSIRO Publishing; 2007. p. 169.

35. EthioSIS (Ethiopia Soil Information System). Soil fertility status and fertilizer recommendation atlas for Tigray regional state, Ethiopia. July 2014, Addis Ababa, Ethiopia. 2014

36. Landon JR. Booker tropical soil manual: a handbook for soil survey and agricultural land evaluation in the tropics and subtropics. Abingdon: Routledge; 2014

37. Asongwe GA, Yerima BPK, Tening AS. Spatial variability of selected physico-chemical properties of soils under vegetable cultivation in urban and peri-urban wetland gardens of Bamenda municipality, Cameroon. Afr J Agric Res. 2016;11(2):74-86.

38. Laekemariam F, Gidago G. Response of maize (Zea mays L.) to integrated fertilizer application in Wolaita, south Ethiopia. Adv Life Sci Technol. 2012;5:21-30.

39. Laekemariam F, Gidago G. Growth and yield response of maize (Zea mays $L$.) to variable rates of compost and inorganic fertilizer integration in Wolaita, southern Ethiopia. Am J Plant Nutr Fertil Technol. 2013;3(2):43-52.

40. Admas H. Soil fertility evaluation and improvement for maize(Zea mays 1.) production in Nitisols of Wujiraba watershed, northwestern Ethiopia. Ph.D. dissertation. Graduate School, Haramaya University, Ethiopia. 2015.

41. Elias $E$, Scoones I. Perspectives on soil fertility change: a case study from southern Ethiopia. Land Degrad Dev. 1999;10:195-206.

42. Alemayehu K, Data D, Ejigu J, Fanuel F, Scoones I, Kelsa K, Tesfaye B, Worku T. A creating garden: The dynamics of soil-fertility management in Wolayta, southern Ethiopia. In: Scoones I, Editor. Dynamics and diversity. Soil fertility and farming livelihoods in Africa. Case studies from Ethiopia, Mali and Zimbabwe. London: Earth scan Publications Ltd; 2001; p. 258.

43. Morris M, Kelly VA, Kopicki RJ, Byerlee D. Fertilizer use in african agriculture: lessons learned and good practice guidelines. Washington, DC: World Bank; 2007.

44. Buyinza M, Nabalegwa M. Effect of slope position and land-use changes to bio-physical soil properties in Nakasongola pastoral rangeland areas, central Uganda. In: Godone D, editor. Soil erosion issues in agriculture. Rijeka: InTech; 2011. P. 241-254. ISBN: 978-953-307-435-1.

45. Ailincăi C, Jităreanu G, Bucur D, Ailincăi D. Long-term effect of fertilizer and crop residue on soil fertility in the Moldavian plateau. Evolut Soil Fertil Under Soil Eros Fertil. 2012;2:29-41.

46. EIAR (Ethiopian Institute of Agricultural Research). Crop research technology recommendations. Addis Abeba, Ethiopia. 2015. http://www.eiar.gov.et.

\section{Submit your next manuscript to BioMed Central and we will help you at every step:}

- We accept pre-submission inquiries

- Our selector tool helps you to find the most relevant journal

- We provide round the clock customer support

- Convenient online submission

- Thorough peer review

- Inclusion in PubMed and all major indexing services

- Maximum visibility for your research

Submit your manuscript at www.biomedcentral.com/submit 